\title{
THE CORRELATION BETWEEN CHARACTER BUILDING AND PEACEFUL THINKING OF STUDENTS AT DARUSSALAM ISLAMIC BOARDING SCHOOL IN PONOROGO, EAST JAVA
}

\author{
Asnawir \\ State Institute for Islamic Studies - Imam Bonjol of Padang \\ e-mail: asnawir@yahoo.com
}

\begin{abstract}
The aim of this research to identify the correlation between the character building and peaceful thinking of students at the Darussalam Islamic Boarding School (Gontor). Character building is a fundamental part of Islamic education in Darussalam Islamic Boarding School as an agenda for educating their students, like: sincerity, simplycity, self-sufficency Islamic Brotherhood and freedom. This is descriptive quantitative research which observation and questionaire were used to colected the data. Population of this research were 400 pupils. Meanwhile, the sample of 200 students were as respondents of this research (simple random sampling). This research was found that there were correlation between character building and peaceful thinking of students. The $\mathrm{r}_{\text {score }}=0,511$ and $\mathrm{r}_{\text {table }}=1,64$ and $\mathrm{p}=0.000,0.05$. It means, $\mathrm{H}_{\mathrm{o}}$ rejected and recieved $\mathrm{H}_{1}$. There were correlation between character building and peaceful thinking of students.
\end{abstract}

\begin{abstract}
Abstrak: Tujuan penelitian ini adalah untuk melihat korelasi antara pembangunan karakter dan pemikiran damai santri Pesantren Darusalam (Gontor). Pembangunan karakter merupakan bagian pendidikan terpenting di Pesantren Darussalam sebagai agenda untuk mendidik santri yang memiliki karakter sederhana, hormat, persaudaraan, dan kebebasan. Desriptif kuantitatif digunakan dengan menggunakan instrument observasi dan angket untuk mendapatkan data. Poulasi penelitian ini adalah 400 santri dengan 200 santri saja terlibat menjadi sampel penelitian ini (Simple Random Sampling). Temuan penelitian ini memperlihatkan adanya korelasi antara pembangunan karakter dan pemikiran damai santri Pesantren Darusalam. Nilai $\mathbf{r}_{\text {score }}=0,511$ dengan $r_{\text {table }}=1,64$ dan $\mathrm{p}=0.000,0.05$. artinya $\mathrm{H}_{\mathrm{o}}$ ditolak dan $\mathrm{H}_{1}$ diterima. Terdapat korelasi antara pembangunan karakter dan pemikiran damai santri
\end{abstract}

Kata Kunci: The Character Building, Islamic Boarding School, Peaceful Thinking.

\section{INTRODUCTION}

Actually, Islam teaches us that diversity is a fact of nature and it makes the nature beautiful. God has created this whole universe with diversity. God says in the Qur'an: ...See you not that Allah sends down rain from the sky? With it We then bring out produce of various colors. And in the mountains are tracts white and red, of various shades of color, and black intense in hue. And so amongst men and crawling creatures and cattle, are they of various colors. Those truly fear Allah, among His Servants, who have knowledge: for Allah is Exalted in Might, Oft-Forgiving (Qs. Fatir/35:27-28). There is diversity among human beings. They have variety of genders, colors and languages and multiplicity of races and tribes. These diversities are considered 
natural and are called "God's signs" in the Qur'an (Qs.30 :20-22). They are indicative of God's creative power and wisdom and are good and healthy since they endow human life with richness and beauty. God wants human beings to derive benefit from this diversity and not to allow it to generate unhealthy schisms and divisions in their ranks. God says in the Qur'an: ...."And from amongst His signs is this that $\mathrm{He}$ created you from dust; and then behold you are humans scattered far and wide. Among His signs is this that $\mathrm{He}$ created for you mates from among yourselves that you may dwell in tranquility with them, and $\mathrm{He}$ has put love and mercy between you. Verily in that are signs for those who reflect. And among His signs is the creation of the heavens and the earth and the variations in your languages and colors; verily in that are signs for those who know. And among His signs is the sleep that you take by night and by day, and the quest that you make for livelihood out of His bounty; verily in that are signs for those who hearken... "(Qs.30 :2023). The diversities of races, families and tribes also have a healthy and constructive purpose, viz. that "you may know each other". In the words of the Qur'an: “....O people, We have created you from a male and a female and made you into races and tribes so that you may know each other. Surely the most honored of you in the sight of God is the one who is the most righteous of you" (Qs. 49:13). Instead of enabling human beings to know each other better, there is no reason why these diversities should create barriers, or cause animosities among human beings.

In addition to these natural diversities there are others that are part of the human societies and cultures. There are diversities of viewpoints. The Qur'an recognizes the individuality of each human being as well as the individuality of their groups and communities. “...To each among you have We prescribed a Law and an Open Way. If Allah had so willed, He would have made you a single People, but (His plan is) to test you in what $\mathrm{He}$ has given you; so strive as in a race in all virtues. The goal of you all is to Allah; it is He that will show you the truth of the matters in which ye dispute" (Qs, 5:48).
Islam does not consider all viewpoints correct or of equal value. However, it is also the fact well recognized in Islam that very often the differences of opinions (ikhtilaf) are also a token of God's mercy. If God had so willed, says the Qur' an, He could have forced people to come together to one point, but he did not do so. God did send His Prophets and Messengers from time to time so that the right path might be made clear through them. As regards the final judgment as to who followed the truth and who did not, that will be made known on the Day of Judgment by God Himself. In keeping with this principle, God forbade His Prophets and the believers from having recourse to coercion in religion. "There is no compulsion in religion", said the Qur'an (Qs. 2:256).

Otherwise, terrorism in Indonesia refer to acts of terrorism that take place within Indonesia or attacks on Indonesian people or interests aboard. These acts of terrorism often target the government of the Republic of Indonesia or foreigners in Indonesia, most notably Western visitors, especially those from the United States and Australia--- Number of cases about the terrorism in Indonesia likes; Borobudur 1985 Jakarta Stock Exchange 2000 Philippine consulate 2000 Christmas Eve 2000 Bali 2002 Marriott Hotel 2003 Aceh 2003 Palopo 2004 Australian Embassy 2004 Poso 2004 Tentena 2005 Bali 2005 Palu 2005 Jakarta 2009 Cirebon 2011---.

Traditionally the militias that politically opposed to Indonesian government interest were held responsible for series of terrorism attack in Indonesia. Separatist movements operating in Indonesia, such as the Darul Islam (Indonesia), Fretilin (East Timorese independence militia during Indonesian occupation of East Timor), Gerakan Aceh Merdeka, and Organisasi Papua Merdeka are often held responsible on terrorist attacks, such as bombings and shootings, in Indonesia. Recent terrorism in Indonesia can in part be attributed to the al-Qaeda-affiliated Jemaah Islamiyah Islamist terror group.

Unfortunoutly, some of Islamic organizations are blamed as terrorist groups. It will spoilt an Islam as a religion and also many kind of Islamic organizations; Islamic party, 
Islamic banking, Islamic social-organization (Indonesian Mujahedeen Council or IMM which leading by Abu Bakar Bashir). ---Abu Bakar Bashir is a schoolteacher. He has white hair, a reedy voice, gold-rimmed glasse and a growing number of close colleagues in foreign jails. Those colleagues, say officials in Singapore, Malaysia, and the Philippines, are part of a sprawling international terrorist conspiracy with links to Al Qaeda led by Mr. Bashir. Bashir, however, remains free to run his Al-Mukmin Islamic boarding school because Indonesia officials say they have insufficient evidence to arrest him. He also runs a growing organization, the Indonesian Mujahidin Council (MMI), which is lobbying to convert Indonesia into an Islamic state. Foreign officials worry that this sends a message to Al Qaeda that Indonesia is a good place to hide. The Islamic movement here is running on parallel tracks political and militant. It has funded paramilitary groups that have ignited sectarian conflicts, conducted vigilante raids on bars and brothels, and burned churches. Bashir has ties to most of these groups through the MMI. Bashir isn't the only militant leader who has been able to make an impact on Indonesia's stability. Last week, the paramilitary group Laskar Jihad ignited another wave of killing in Maluku province, where thousands have been killed in sectarian violence since 1999. Indonesian officials had hoped that a three-month lull in the violence and a peace agreement signed in February meant the worst was over. But militants such as Bashir and Laskar Jihad leader Jaffar Umar Thalib had attacked the peace deal and vowed to bring it down. http://www.csmonitor.com/.....During President of Indonesia Suharto's New Order, Bashir and Sungkar were arrested for a number of reasons, firstly for actively supporting Sharia, the non-recognition of the Indonesian national ideology Pancasila which in part promotes religious pluralism. Secondly, the refusal of their school to salute the Indonesian flag which signified Bashir's continual refusal to recognise the authority of a secular Indonesian state. Bashir appealed but was subsequently imprisoned without trial from 1978 to 1982.(www.cfr.org/publication) Soon after his release, Bashir was convicted on similar charges; he was also linked to the bomb attack on the Buddhist monument Borobudur in 1985 but fled to Malaysia. (www.cfr.org/publication) During his years in exile Bashir undertook religious teachings in both Malaysia and Singapore. The United States government alleged that during this period he became involved with Jamaah Islamiyah, an alleged militant Islamist group (Australian Department of Foreign Affairs and Trade dlm.http://en.wikipedia.org/) Bashir remained in exile until Indonesian President Suharto's fall in 1998. (Lee hudson Teslik dlm. http:// en.wikipedia.org/) Bashir returned to Indonesia in 1999 and became a cleric, renewing his call for Sharia law.--- Islamic school and including Islamic Boarding School.-Amid widespread prejudice, which relates their school to terrorism, students of Al-Mukmin Islamic Boarding School in Ngruki, Sukoharjo, Central Java. www. Thejakartapost.com. Wednesday, August 11 2010.--- So, Islam and Muslims are still the target of stereotyping and misrepresentations. The United Nations' Commission on Human Rights last week adopted a resolution expressing its deep concern regarding the stereotyping of religion, particularly Islam, as a faith that has been "wrongly associated with human-rights violations and with terrorism."(Muzammil $\mathrm{H}$. Siddiqi. Unity and Diversity. In http://www. islamfortoday.com) Although the language of the draft resolution appeared unthreatening as it used such general terms as "human rights, social harmony, and religious and cultural diversity," the measure narrowly passed with 15 members choosing to vote against it, and 9 others abstaining.

This reserch did not want to put inside at the conflict of interest, weather Islamic Boarding School had any connection with terroism or not. But, the reserach wanted to be explained about the character building in Islamic Boarding School and Peaceful Thinking of students at the Darussalam Islamic Boarding School (Gontor) in Ponorogi, East Java.

\section{THE PROBLEMATIC IDENTIFICATION}

Character is the solid foundation on which a person's entire life is based. History has, time and again, thrown the statistics at us. Men 
of good character have been remarkably successful. Whether it was Thomas Edison whose inventions changed the world, or it was Abraham Lincoln who was president of the United States, or Gandhi the lone crusader of nonviolence, or Mother Theresa who chose to do social work they all had one thing in common- they were all people of character. Character is the magic ingredient that sets you apart from the rest. Our character will determine our success and each of us has the ability and the potential to develop and strengthen our character. Character is a potpourri of many qualities like honesty, integrity, dependability, diligence, loyalty, compassion, sincerity, attentiveness, determination, confidence, etc. All these traits and many more sum up one's character.

Everyone has character. It is our character that defines who we are and what we will become. Some people have more fully developed, some qualities, which set them apart from the rest. While character has much to do with the mental and ethical traits that make a person, it actually refers to the unique qualities that are built into an individual's life which establish his reaction despite his circumstances. Although character might mean a lot of qualities, the fact is that all the qualities are kind of inter-related. If you are honest automatically you are more dependable, more responsible, and more conscientious. When our overall character improves, it translates into success in all the areas of our lives.

Often we tend to disregard the direct influence character has on our successes or failures. When you consider the individual qualities that come together to make ones character then it becomes easier to understand how character affects our lives. If you are honest at work, it will directly relate to your dependability which in turn will translate into better work being sent your way. If you are discreet, then people will be keener on sharing their knowledge with you.

If you are diligent, better offers will come your way. If you are compassionate, you will receive the goodwill and the blessings of both your peers and your friends. The youth of today live in troubled times. The stuff that is dished out in the name of entertainment and news fills the minds of the young with all the wrong things. These are tough times and children are often weak and give into peer pressure. The youth of today face grave problems such as substance abuse, gang activity, school dropouts, vandalism, juvenile delinquency, teen pregnancy and youth violence. These are all moral issues having much to do with our ethics.

There are no easy solutions. If any kind of long-term solution is hoped to be achieved we will have to go to the grass roots-the core values. Children who have strong sense of values will be under lesser pressure to succumb because there is already support system and it is not outside them, it is within. Core values give them the ability, the courage to stand up for what they believe in. Character is the tree and habits are the seeds you sow to reap it. If you invest in good habits, you will have reaped character and if you invest in character you will reap destiny.

Character building forms a integral part in school, marriage counseling, sports settings and work settings as well. In a nutshell, it can be rightly said that character building has turned out to be a hot topic in today's world. But the question that possibly clicks on everybody's mind is that "What's so unique about character building or rather why you think character building is so important?" Well, one of the prime reasons behind this growing popularity because of the fact that it is the chief purpose of our lives. And you will be surprised to know that character building and success are the two opposite sides of the same coin. --- We do not often think of character as having such a direct effect on our successes or failures. But when we consider the individual qualities that together make up a person's character, we can easily see that it does. Students who struggles with math can often succeed by being diligent to study and work problems every day and by showing endurance when he/she is tired and would like to quit. Magic Johnson, one of basketball's alltime great players, developed his skills in part by practicing every day as a youth. $\mathrm{He}$ demonstrated determination and persistence. Abraham Lincoln became President after 
repeatedly losing elections for lower offices. His character was such that he would not give up.There are endless examples... how attention to detail has made the difference, how diligence has paid off, how a person's dependability has put them in line for promotion.There also are many, many negative examples. Richard Nixon's failure to be truthful evenually led to his downfall. O. J. Simpson's apparent lack of self-control caused extreme problems for him. A student's lack of diligence led to him not being able to complete his course of study. Character Really Does Determine Success.---To begin with, you cannot attain your desired thing in life unless and until you possess a good character.

\section{THE RESEARCH PROBLEM}

This research had three problematic which tried to find the answer:

(1) Describing about the character building in Islamic Boarding School?

(2) Describing about the peaceful thinking of students at the Islamic Boarding School.

(3) Describing about the correlation between character building in Islamic Boarding School and peaceful thinking of students at Darussalam Islamic Boarding School in Ponorogo, East Java.

\section{THE RESEARCH OF SIGNIFICANCE}

There were two kinds of research significance in this research: (1) Theoritical significance, the research hopefully could be developed the theoritical background and supporting the wider of social-psychology knowledge it self. (2) The practical significance, the reseach could be given benefit to the Kyai and Ustandz and also students at the Islamic Boarding School (especially Darussalam Islamic Boarding school), Beside that it will be benefit to the society (steakholders) which connected with the Darussalam Islamic Boarding School. Then, the research would be benefit to the government for making policy about the Islamic Boarding School.

\section{THE RESEARCH FINDING DISCUSSION}

There were two kinds of research finding in this research: (1) Descriptive analysis of respondent and spreading of mean data of variables. (2) The quanitiative analysis and testing of the hypotesis.

The Descriptive Analysis of Respendent

Table 1.1: The Descriptive Analysis of Respondent

\begin{tabular}{|c|c|c|}
\hline & The Categories & Frequency \\
\hline & Thee Education level & \\
\hline 1 & Junior high scool & 109 \\
\hline \multirow[t]{3}{*}{2} & Senior high school & 91 \\
\hline & Sum & 200 \\
\hline & Ages & \\
\hline 1 & $12-14$ years old & 115 \\
\hline \multirow[t]{3}{*}{2} & $15-17$ years old & 85 \\
\hline & Sum & 200 \\
\hline & The economic background & \\
\hline 1 & $\begin{array}{l}\text { High level of economic } \\
\text { background (family income } \\
>\text { Rp } 10.000 .000 / \text { month) }\end{array}$ & 32 \\
\hline 2 & $\begin{array}{l}\text { Medium level of economic } \\
\text { background (family income } \\
\text { Rp } 5000.000-\text { Rp } \\
10.000 .000 / \text { month) }\end{array}$ & 89 \\
\hline \multirow[t]{3}{*}{3} & $\begin{array}{l}\text { Lower level of economic } \\
\text { background (family income } \\
<\operatorname{Rp} 5000.000 \text { / month) }\end{array}$ & 79 \\
\hline & Sum & 200 \\
\hline & The parents employee & \\
\hline 1 & Civil servent & 52 \\
\hline 2 & Teachers / Lecturer & 38 \\
\hline 3 & Enterprenour / private sector & 95 \\
\hline \multirow[t]{3}{*}{4} & Public service & 15 \\
\hline & Sum & 200 \\
\hline & $\begin{array}{c}\text { The family social- } \\
\text { organization } \\
\text { background }\end{array}$ & \\
\hline 1 & Nahdlatul Ulama & 112 \\
\hline 2 & Muhammadiyah & 78 \\
\hline 3 & Persis & 10 \\
\hline
\end{tabular}




\begin{tabular}{l|l|l}
\hline & Sum & 200 \\
\hline Sources: The reserach reports
\end{tabular}

Sources: The reserach reports

According to table 1.1 we found that most of the student at the Darussalam Islamic Boarding School studied at the junior high school level. Then, most of the ages of students at the Darussalam Islamic Boarding school between $12-14$ years old. This research found that most of the respondent were coming from medium economic background. Beside that, the research also found that most of the paents employees were enterprenour or private sector. After that, most of family social-organizational background was Nahdlatul Ulama.

Table 2.1 The mean spreading, frequency and percentage of character building

\begin{tabular}{l|l}
\hline The Categories & Frequency \\
\hline High & 138 \\
\hline Low & 62 \\
\hline Sum & 200 \\
\hline
\end{tabular}

Sources : The research reports

According to the table 2.1 above, most of mean spreading were locating at the high level. It means that the character building which implemented in Darussalam Islamic Boarding School had internelized in their students bevahior, especially about their five spirits : Sincerity, simplicity, self-sufficiently, Islamic brotherhood, and freedom.

Table 3.1 The mean spreading, frequency and percentage of peaceful thinking

\begin{tabular}{l|l}
\hline The Categories & Frequency \\
\hline High & 182 \\
\hline Low & 18 \\
\hline
\end{tabular}

\begin{tabular}{l|l}
\hline Sum & 200 \\
\hline
\end{tabular}

According to the table 3.1 above, most of mean spreading were locating at the high level. It means that most of the studnets at the Darussalam Islamic Boarding School had a peaceful thinking; they never wanted to involved with any kinds of violence (bullying, crime activities, etc). Beside that, the Darussalam Islamic Boarding School never tolerate with nay kinds of violence. So, they never thought about the violence activities. They always try to make confortable condition to study and playing.

Table 4.1 The Hypotesis Analysis

\begin{tabular}{|c|c|c|c|}
\hline & & $\begin{array}{l}\text { Character } \\
\text { Building }\end{array}$ & $\begin{array}{l}\text { Peaceful } \\
\text { Thinking }\end{array}$ \\
\hline \multirow[t]{3}{*}{$\begin{array}{l}\text { Characte } \\
\text { Building }\end{array}$} & $\begin{array}{l}\text { Pearson } \\
\text { Correlation }\end{array}$ & 1 & $.511(* *)$ \\
\hline & Sig. (2-tailed) & & .000 \\
\hline & $\mathrm{N}$ & 200 & 200 \\
\hline \multirow[t]{3}{*}{$\begin{array}{l}\text { Peaceful } \\
\text { Thinking }\end{array}$} & $\begin{array}{l}\text { Pearson } \\
\text { Correlation }\end{array}$ & $.511(* *)$ & 1 \\
\hline & Sig. (2-tailed) & .000 & \\
\hline & $\mathrm{N}$ & 200 & 200 \\
\hline
\end{tabular}

According to the table 4.1 above, we got information that $\mathrm{r}$ score $=0.951$. Then the table score $=1,64$ and $p=0.000<0.05$. It means $\mathrm{H}_{\mathrm{o}}$ was rejected and recieved $\mathrm{H}_{1}$. So, there were any correlation between character building and peaceful thinking of students at Darussalam Islamic Boarding School.

\section{DISCUSSION}

As far as the history of Islamic education in Indonesia is concerned, modern pesantren can be regarded as new genre of pesantren. The Pesantren Darussalam of Gontor, Ponorogo, was established in 20 September 1926 by three brothers - KH. Ahmad Sahal, KH. Zainuddin Fannani, and KH. Imam Zarkasyi. This pesantren is also called pondok modern (modern pesantren), in a sense that it not only adopts madrasah system, but also teaches Arabic and English to the students 
intensively and practically. In daily conversation among the students within the pesantren, all santris are obliged to speak Arabic or English - they are not allowed to speak Indonesian. In addition, unlike the majority of other pesantrens, pondok modern Darussalam, Gontor includes the works of reformist Muslim thinkers in its curriculum. The works of Abduh, for instance, are placed as important subject matters in the pesantren.

The objective of Pesantren Gontor, as mentioned by Lance Castle (1966), is to produce kader Muslim (Muslim cadres) by combining the excellences of both traditional and modern pesantren education systems. In addition to secular subjects, the pesantren also urges the santris about the significance of art. Accordingly, music, sport and other extracurricular activities are among the concerns of pesantren's leaders. The pesantren is also intended to provide education capable of responding to Muslim challenges amid the socio-cultural life of Indonesian society which begin to enter modern world.

It is important to mention that Pesantren Gontor was established in the crucial period of Islamic development in Indonesia. Following the ethical politics implemented by the Dutch colonial administration, coupled with the establishment of international network with the center of Islamic reform in Cairo, Egypt, the Islamic education in Indonesia went through fundamental changes. This was marked by the establishment of new Islamic educational institutions, which adopt modern education system, instead of traditional education system of pesantren. The modern Islamic education institution - well-known as madrasah - then became an important part of Islamic reform movement during the early decades of 20th century.

Accordingly, in addition to introduce new system and instructional methods ranging from adopting grading model with class division, employing text books as learning tools, to accommodating secular subjects in the curriculum - madrasah functioned also as a media for the dissemination of Islamic reform ideas. It became the basis to prepare new Muslim generations who are familiar with the spirit of modernism, an issue that at that time was an overwhelming discourse in Indonesia which started to enter modern world. Accordingly, kader Muslims to be produced by Pesantren Gontor are those who are frequently identified as "Muslim intellectuals".

The self-definition of Pesantren Gontor as a modern pesantren, as has been mentioned, is basically aimed at attempting itself to be in contrast to traditional pesantren, which is to some extent identical to stagnancy of thought, and to ineffective as well as inefficient managerial system of education. Imam Zarkasyi, one of the founding fathers of Pesantren Gontor, is of the opinion that a modern pesantren should implement freedom of thought, effective and efficient management, and introduce santri toward modernity. Parallel to other reformist Muslim, he also invites Muslims not to be too fanatical towards a certain madhhab, since this would lead to the absence of the freedom of thought. Indeed, with regard to religious ritual practices, Pesantren Gontor is not fanatical to a certain madhhab.

As far as the relation of pesantren and modernism is concerned, the effective and efficient management are described that pesantren should adopt a good, accountable and transparent administration and accounting system. Moreover, the managerial system of modern pesantren relates to the leadership system of pesantren. In this regards, Pesantren Gontor from its inception came up with an idea of what is termed as badan wakaf, the highest body within pesantren in which discussion and decision making are conducted. Under the badan wakaf is badan pelaksana (organizing body) which is responsible of the daily affairs of the pesantren. On the other hand, the introduction of santris toward modernity is implemented by providing them with Arabic and English language skills, Boy Scout, skills, and sports - activities unusual for traditional pesantrens.

The manifestation of modern education of Pesantren Gontor can be seen from KMI (Kulliyatul Muallimin al-Islamiyah) system, i.e. a six-year secondary level of education (equal to SMP and SMU). In this respect, KMI constitutes a combination between madrasah 
and pesantren system. The decision to adopt this kind of education system was influenced by the school experiences of Imam Zarkasyi, from a pesantren in Solo, Thawalib of Padang Panjang in Sumatra, and Normal Islam School or also called Kulliyatul Muallimin al-Islamiyah. In addition, it is also important to note here his experience in establishing and being the director of Muhammadiyah Kweekschool in Padang Sidempuan. With all those experiences, Imam Zarkasyi then tried to combine pesantren and modern school. The KMI is a madrasah plus pesantren.

Thus, the concept of modern pesantren introduced by Imam Zarkasyi has become a blueprint and genre for the development of the next modern pesantren. Zarkasyi's students who are now spreading all over Archipelago establish a number of similar pesantren pioneered by the kyai. During the period of 1970-80s, a couple of Gontor alumni established pesantrens in their own region. In Banten, Pesantren Daar El-Qalam was established in Gintung Balaraja; in Madura Pesantren AlAmin was established in Prenduan Sumenep; in Central Java Pesantren Pabelan was established in Pabelan; Pesantren Modern Assalaam was established in Solo; and many others.[10] Those pesantrens are frequently called pesantren alumni (meaning the alumni of Gontor), the second generation which have influenced the model of other modern pesantrens in their later development.

It should be noted that in the course of its development, pesantren alumni are not always implementing the standardized model of Pesantren Gontor. The Modern Pesantren Assalaam, for example, has developed a different model. The full name of this pesantren is Pondok Pesantren Modern Islam (PPMI) Assalaam, located in Pabelan, Kartasura Sukoharjo, Central Java. At the outset, Pesantren Assalaam is a branch of Pesantren Ngruki, which will be discussed exclusively in this paper. In the beginning of 1980s, when Pesantren Ngruki began to operate, the capacity of the pesantren could not accommodate all the registered students because of an overwhelming interest of parents to send their children to Pesantren Ngruki. Consequently, a decision was made to find another location to accommodate the students. A spot in Pabelan village located in Kartasura was eventually chosen as location to establish a pesantren. The new pesantren was named Assalam. As a branch of Pesantren Ngruki, Pesantren Assalam received supports from Ngruki, including teaching staff.

In due course, Pesantren Assalam, which was established in 7 August 1982, has grown rapidly in terms of the number of students, even surpassing the number of students in Pesantren Ngruki itself. Approximately 2000 students have been registered in Assalam, while Ngruki has around 1500 students. The origin of learning system in Pesantren Assalam was an MDA (Madrasah Diniyah Awaliyah) which was conducted in the evenings. In 1982, to answer the request of neighboring community, a Madrasah Tsanawiyah was established by employing dormitory system. At this juncture, a pesantren system had begun to be introduced, in which students were studying extra courses, adopted from pesantren curriculum. A quite significant measure was taken by Assalam when it received a relatively spacious wakaf land $(92,845 \mathrm{~m} 2)$ from Abdullah Marzuki, a printing entrepreneur of PT Tiga Serangkai, Solo. Now, the property of Assalam is 10.223 ha lands, with 5.6 ha of them are wakaf lands.

At its very inception, the teaching staff of Assalam was supplied from Pesantren Ngruki and some of Gontor alumni who wanted to have teaching experience. Having been able to produce its own graduates, Pesantren Assalam then began to fulfill its own staff. However, the teachers, especially those who teach sciences, are from universities in Surakarta. There are some requirements for someone to be eligible to become teaching staff at Pesantren Assalam. In addition to the readiness of teaching relevant expertise, an applicant should understand the vision and mission of the pesantren. Furthermore, morality of the applicant is the most important aspect to consider in the recruitment process.

Assalam has developed as a big pesantren in Surakarta. This achievement is not only due to its consistency in implementing the concept of modern pesantren as has been 
introduced by K.H. Imam Zarkasyi, but also because of its attainment in developing modification for pragmatic needs. This can be seen in terms of curriculum and grading system. Although Assalam adopts Gontor's curriculum, but it also implements national curriculum developed by MORA and MONE. As for grading or leveling system, Assalam implements its own system, i.e. Tsanawiyah (3 years), Aliyah (3 years), SMU (3 years) and Takhassusiyah (Tsanawiyah + Aliyah +1 year).

The above grading system is actually out of the standardized grading model developed by Gontor, which implements the KMI system, in which Tsanawiyah and Aliyah are regarded as one single level, so that there is no graduation process from grade 3 to grade 4 . This system has been maintained in Gontor up to the present time. As for curriculum, Gontor still implements the curriculum developed by K.H. Imam Zarkasyi some decades ago. Meanwhile, Assalam tries to modify curriculums developed by Gontor, MORA and MONE.

What has been performed by Pesantren Assalam is obviously contradictory to the principle embraced by K.H. Imam Zarkasyi, the founder of Pesantren Gontor. According to Zarkasyi a curriculum must be standardized, and should remain unchanged if necessary. He criticized the government policy which has changed national curriculum quite often. Once an educator is convinced that the curriculum he designed can be applied well, he has to implement the curriculum. However, it is worthy noted that by the time Gontor curriculum was developed, Zarkasyi was in a situation where curriculum standardization was not a national discourse. Now, his students face an era in which curriculum standardization is necessary to maintain quality of education. The adoption of national curriculum by pesantren alumni gained momentum in 1980s. Nevertheless, the characteristic of Pesantren Gontor which emphasizes Arabic and English languages is still maintained.

Even though some of pesantren alumni have not been adopting Gontor curriculum anymore, few of them are still implementing the Gontor standardized model. Accordingly, there emerge terms: pure Gontor and non-pure
Gontor. The pure Gontor is a term addressed to pesantrens which follow Gontor tradition per se. Meanwhile non-pure Gontor are those which, in addition to adopt Gontor's curriculum, implement national and local curriculum. The emergence of terms pure Gontor and non-pure Gontor do not merely show the two variants of pondok modern, but sometimes they provoke conflict between pesantren alumni and Pesantren Gontor itself. Gontor desires pesantren alumni to imitate its model. Meanwhile, the later want to make modification and adjustment in line with community interests. Sometimes the conflict is more complex than merely a matter of curriculum and grading system, let alone pertaining social recognition and influence. Pesantren Al-Zaitun, located in Indramayu, West JAva, can be categorized as pesantren alumni. Panji Gumilang AS was the student of K.H. Imam Zarkasyi. Although Pesantren Zaitun was established few years ego, it has been going through so amazing development that provoked bad news and jealousy from other pesantren. It is informed that there is unharmonious relationship between Gontor and Zaitun, since they compete to gain influence and recognition from society.

There is another modification carried out by pesantren alumni, especially regarding Islamic 'Aqi>dah course. Pesantren Gontor is considered not so strong enough in teaching 'Aqidah that makes its alumni have various religious-ideologies. The Gontor alumni vary, ranging from a reformist Nurcholish Madjid, an intellectual who brought forth Islamic reform, to a conservative such as Kyai Khalil Ridwan, the leader of Pondok Pesantren Al-Husnayain. This phenomenon, according to Khalil Ridwan himself, who also the leader of BKSPP (Badan Kerjasama antar Pondok Pesantren) - a forum for Gontor alumni - is resulting from limited education of "Aqidah in Gontor so that santri experience ideological disorientation.

One thing to be kept in mind in discussing Pesantren Gontor and pesantren alumni is their contribution in establishing new foundation for the development of pesantren in Indonesia. Moreover, the modern education system of Gontor at the same time also introduced santri towards some principles of 
modernity. Besides various facilities, there are a number of significant aspects which can be regarded as being supportive to the implementation of modern principles, which can be taken from the courses in pesantren, especially fiqh, us $\} \mathrm{u}>1$ al-fiqh, al-adya $>$ n (comparative religion), and Civics. These courses are potential to socialize the values of pluralism, because they admit diversity both in the idea and practical levels. It is the recognition of the existing different opinion that in turn leads the santris to have tolerant attitude, one of the significant values of modernity.

\section{CONCLUSION}

Darussalam Islamic Boarding School to promote unity in diversity: (1) As the Islamic Boarding School Darussalam (gontor) thought that the other cultures and religions should not be misrepresented. Educational institutions and media outlets should be held responsible not to propagate or perpetuate hate against any group of people and their recognized faiths and values. (2) Tolerance must be practiced on all levels: individual, groups and states. It should be a political and legal requirement. Tolerance is the responsibility that upholds human rights, pluralism (including cultural pluralism), democracy and the rule of law. (3) There are several levels of tolerance. But we can emphasize two levels here in: (a) Tolerance between the members of the same community and same religion. As we are aware people of the same religion have differences of interpretation and understanding. Although they have common sources, common principles but they do vary in their interpretation due to various reasons. Here we need intercommunity dialogues and building of relations to minimize contradictions and inconsistencies in our thinking or behavior. (b) Tolerance between the people of different faiths and cultures. Here we need interfaith relations and dialogues. Of course we have core differences in our religions but we must try to understand each other. As we learn about our own faith traditions and communities, we should also learn about others. Someone rightly said, "Understanding others changes us." By understanding we learn the areas of commonalities as well as differences.
We can learn the nature of differences and the extent of differences. We must look what kind dialogues could be of value, and what issues are most in need of respectful dialogue in these times. What concerns for the well-being of others should drive our efforts to reach common ground for action. Each group must encourage and facilitate shared responsibility to create a more sensitive and welcoming environment for our diverse groups.

\section{REFERENCES}

Abaza, Mona, 1994. Islamic Education, Perceptions and Exchanges: Indonesian Students in Cairo, Paris: Cahier de Archipel

Abdullah, Taufik, 1987. Islam dan Masyarakat: Pantulan Sejarah Indonesia, Jakarta: LP3ES

Adil, 31 Januari 2002.

Al Chaedar, 1999. Pemikiran Politik Proklamator Negara Islam Indonesia S.M. Kartosoewirjo: Fakta dan Data Sejarah Darul Islam, Jakarta: Darul falah, 1999

Al Chaedar, 2000. Sepak Terjang KW IX: Abu Toto Syekli AS Gumilang Menyelewengkan NKA-NII Pasca SM Kartosuwirjo, Jakarta: Madani Press

Alatas, Alwi dan Fefrida Desliyanti, 2002. Revolusi Jilbab: Kasus Pelarangan Jilbab di SMA Negeri Se-Jabotabek 1982-1991, Jakarta: Al-I'tishom

Ali, Fachry dan Bahtiar Effendy. 1986. Merambah Jalan Baru Islam: Rekonstruksi Pemikiran Islam Indonesia Masa Orde Baru, Bandung: Mizan

Anggaran Dasar dan Anggaran Rumah Tangga Yayasan Pendidikan Al-Mukmin Surakarta, 1992. Surakarta: YPIA

Aqidah 1a \& 1b, (Surakarta: PP Islam AlMukmin Ngruki, t.t.)

Assegaf, Farha Abdul Kadir, 1995. Peran Perempuan Islam: Penelitian di Pondok Pesantren Al-Mukmin, Sukoharjo, Jawa Tengah, Tesis S-2 pada Program Studi Sosiologi Universitas Gajahmada Yogyakarta 
Awwas, Irfan S. (ed.), Mengenal Majelis Mujahidin: Untuk Penegakan Syariah Islam, Yogyakarta: Markaz Pusat Majelis Mujahidin

Awwas, Irfan S., 1982. Perjalanan Hukum di Indonesia, Yogyakarta: Ar-Risalah

Azra, Azyumardi, 1992. "The Transmission of Islamic Reformism to Indonesia: Network of Middle-eastern and MalayIndonesian "Ulama" in the Seventeenth and Eighteenth", Ph.D dissertation, Colombia University, New York

Benda, Harry Jindrich. 1980. Bulan Sabit dan Matahari Terbit: Islam Indonesia pada Masa Pendudukan Jepang. Jakarta: Pustaka Jaya

Bidang Tarbiyah PP Persis. 1996. Pedoman Sistem Pendidikan Persatuan Islam. Bandung: PP Persatuan Islam

Boland, Bernard Johan. 1982. The Struggle of Islam in Indonesia 1945-1947. Leiden: E.J. Brill

Bruinessen, Martin van, 1995. Pesantren dan Kitab Kuning: Pesantren dan Tarekat, Jakarta: Mizan

Damanik, Ali Said, 2002. Fenomena Partai Keadilan: Transformasi 20 Year Gerakan Tarbiyah di Indonesia, Jakarta: Teraju

Dhofier, Zamakhsari, 1995. Tradition \& Change In Indonesian Islamic Education, Jakarta: MORA

Dhofier, 1984. Zamakhsyari. Tradisi Pesantren: Studi tentang Pandangan Hidup Kyai. Jakarta: LP3ES

Direktori Pondok Pesantren Proyek Peningkatan Pondok Pesantren, 2000, Direktorat Pembinaan Perguruan Agama Islam Direktorat Jenderal Pembinaan Kelembagaan Agama Islam Departemen Agama

Effendy, Bahtiar, 1994. Islam and the State: The Transformation of Islamic Political Ideas and Practices in Indonesia, Michigan: UMI Dissertation Services

Encyclopaedia Britannica Deluxe Edition CDROM.

Ensiklopedi Islam di Indonesia, Departemen Agama, 1992/1993.
Federspiel, Howard M. 1970. Persatuan Islam: Islamic Reform in Twentieth Century Indonesia. New York: Cornell University

Feisal, Yusuf Amir. 1993. "Pesantren Gaya Baru, Sebuah Usulan.” Risalah, No. 7/Nopember 1993

Gamma: Indonesian Digital news, 03 Februari 2002

Geertz, Clifford, 1960. "The Javanese Kijaji: the Changing Role of a Cultural Broker", CSSH, vol. 2

Geertz, Clifford, 1960. The Religion of Java, New York: The Free Press

Hadi, Noor (ed.), Mengenal Sekilas Pondok Pesantren Islam "Al-Mukmin" Ngruki Surakarta, Solo: Litbang PP Islam AlMukmin

Hamid, Abu, 1983. "Sistem Pendidikan Madrasah dan Pesantren Di Sulawesi Selatan”, dalam Taufik Abdullah (ed), Agama dan Perubahan Sosial, Jakarta: Rajawali Press

Hamid, Hamdani. 1993. Usaha Pembaharuan Pendidikan: Perubahan Kurikulum Pesantren Persatuan Islam. Bandung: CV. Dasita

Hamzah, Abu Bakar, 1981. Al-Imam: Its Role in Malay Society 1906-1908, Kuala Lumpur: Pustaka Antara

Horikoshi, Hiroko, 1987. Kiyai dan Perubahan Sosial, Jakarta: P3M

Hurgronje, C. Snouck, 1996. "Seorang Rektor Universitas Mekah”, dalam, Kumpulan Karangan Snouck Hurgronje, Jakarta: INIS

Hurgronje, C. Snouck, 1931. Mekka in the Latter Part of the 19th Century, Leiden: E.J. Brill

International Crisis Group (ICG), Al-Qaeda in the Soutbeas Asia: The case of the "Ngruki Network" in Indonesia, www.crisisweb.org

J.A., Denny J.A., 1990. Gerakan Mahasiswa dan Politik Kaum Muda Era 80-an Jakarta: CV Miswar

Jabir, Husain ibn Muhsin ibn Ali, 1984. AlThariq ila Jama'ah al-Muslimin, Kuwait: Dar al-Dakwah

Jawa Pos: Radar Yogya, 20 September 2002 
Johns, A.H., 1980. From Coastal Settlements to Sekolah Islam and City: Islamization in Sumatra, the Malay Penensula and Java", dalam, Indonesia: The Making of A Culture, Canbera: Research School for Pacific Studies

John Paul Lederach, 1997. Building Peace: Sustainable Reconciliation in Divided Societies, Washington: US Institute of Peace

Joan V. Bondurant, 1988. Conquest of Violence: The Gandhian Philosophy of Conflict, Princeton: Princeton University Press

Karim, M. Rusli, 1985. Dinamika Islam di Indonesia: Suatu Tinjauan Sosial dan Politik, Yogyakarta: Hanindita

Kartodirdjo, Sartono, 1966. The Peasant Revolt of Banten in 1888: Its Conditions, Courses, and Sequel, The Hague: Martinus Nijhoff

Laporan Akhir Akreditas KMI, 2004. PPIM UIN Jakarta

Laporan Akhir Studi Pengembangan Sub-Sektor Pendidikan Madrasah pada Proyek Peningkatan Perguruan Agama Islam Tingkat Menengah ADB Loan 1519INO, 2003, Jakarta: PT Amythas Experts and Associates

Manguluang, Hamzah, Riwayatku dan Riwayat Guru Besar Kyai H.M. As'ad. Sengkang (terbitan sendiri);

Matheson, Virginia dan M.B. Hooker, 1988. "Jawi Literature in Patani: the Maintenance of an Islamic Tradition”, JMBRAS, vol. 16, I

Nagazumi, Akira, 1972. The dawn of Indonesian nationalism: The early years of Budi Utomo, 1908-1918, Tokyo: Institute for Developing Economies

Noer, Deliar, 1980. Gerakan Modern Islam di Indonesia 1900-1942, Jakarta: LP3ES

Nurmawan. 1997. "Quovadis Persatuan Islam?." Risalah. No. 5 Th. XXXV, Juli

Nursalim, Muh, 2001, Faksi Abdullah Sungkar dalam Gerakan NII Era Orde Baru, Thesis pada Program Magister Islamic Studies di Universitas Muhammadiyah Surakarta
Othman, Mohammad R., 1994. "The Middle Eastern Influence on the Development of Reli-gious and Political Thought in Malay Society, 1880-1940”, Dissertasi Ph.D., Uni-ver-sity of Edinburgh

Pimpinan Pusat As'adiyah, 1982. Setengah Abad As'adiyah 1930-1980. Sengkang Kab. Wajo Sulawesi Selatan

Rahman, Ahmad, Guruta H. Muhammad As'ad Al-Buqisiy (Pelopor Pendidikan di Sulawesi Selatan), 1996. Seminar Hasil Penelitian Rutin (tidak diterbitkan), Badan Litbang Agama, Balai Penelitian Lektur Keagamaan Ujung Pandang

Risalah, 1993. "Menuju Pesantren Mumpuni." No. 7/Nopember 1993

Risalah, 1983. "Pajagalan...Riwayatmu." No. 4, Th.XXVII, Juni 1989

Risalah, "Persis dalam Perspektif Sejarahnya." No. 3, XXVIII/Mei 1990, h. 12-16.

Risalah. 1985. "Pesantren Persis Pajagalan." No. 1, Th. XXIII, Jumadits Tsaniyah 1405 H/Maret 1985

Raymond Helmick and Rodney Peterson, eds. 2001. Forgiveness and Reconciliation: Religion, Public Policy and Conflict Transformation Philadelphia: Templeton Foundation

Ristiyanto, Sugeng, 2000. A Study on Management Perspective in Relation to the Existance of Islamic Institution: Pesantren Islam AI-Mukmin Ngruki Sukoharjo, Thesis pada Program magister Islamic Studies di Universitas Muhammadiyah Surakarta

Ronald Alan Lukens-Bull, 1997. A Peaceful Jihad: Javanese Islamic Education and Religious Identity Construction, $\mathrm{PhD}$ Dissertation, Arizona State University

Rosidi, Ajip. 1990. M. Natsir: Sebuah Biografi. Jakarta: Giri Mukti Pusaka

Sabili, 2002. No. 16 YEAR. IX 8 Februari 2002. Sabili, 2002. No. 16 Year. IX 8 Februari 2002.

Saidi, Ridwan. 1985. "PERSIS yang Saya Alami." Risalah, No. 5, Th. XXIII Dul Qo'dah 1405 H/VII 1985.

Santosa, June Chandra, 1996. Modernization, Utopia and the Rise of Islamic 
Radicalism in Indonesia, Dissertation in Boston University

Setiawan, Aking. 1985. "Mencari Rumusan Tujuan Pendidikan Pesantren." Risalah, No.3, Th.XXIII Sya'banRamadhan 1405 H/Mei 1985.

Statistik Madrasah Indonesia 2002-2003, Depag.

Statistik Pondok Pesantren Indonesia 2002-2003, Depag

Steenbrink, Karel A., 1986. Pesantren, Madrasah dan Sekolah: Pendidikan Islam dalam Kurun Modern, Jakarta: LP3ES

Suara Hidayatullah, 10/XIII/ Februari 2001.

Tapol, 1987. Indonesia: Muslims on Trial, London: Tapol

Turmudi, Endang. 1995. "The Charismatic Leadership of The Kyai in Contemporary East Java: Field Notes from Jombang”, dalam Masyarakat Indonesia: Majalah Ilmu-Ilmu Sosial Indonesia, year XXII nomor 2, Jakarta: LIPI.

Tony Devine, Joon Ho Seuk and Andrew Wilson, 1996. Cultivating Heart and Character, (Chapel Hill, NC: Character Development Publishing, 2000). Exposition of the Divine Principle, New York: HSA-UWC

Umam, Saiful dan Azyumardi Azra, 1998. Tokoh dan Pemimpin Agama: Biografi Sosial-Intelektual. Jakarta: Badan Litbang Agama, Departemen Agama
UU No. 20, 2003 tentang Sistem Pendidikan Nasional (Sisdiknas)

UU No.4, 1950; UU No. 12 year 1954

Wahid, Abdurrahman,1974. "Pesantren sebagai Subkultur", dalam M. Dawam Rahardjo, (ed.), Pesantren dan Pembaharuan, Jakarta: LP3ES

Wijoyo, Alex Soesilo, 1997. "Shaykh Nawawi of Banten: Texts, Authority, and The Gloss Tradition”, Ph. D. Dissertation, Colomnia University, New York

Wildan, Dadan, 1995. Sejarah Perjuangan Persis 1923-1983. Bandung: Gema Syahida

Wildan, Dadan, 1997. Yang Da'i Yang Politikus: Hayat dan Perjuangan Lima Tokoh Persis. Bandung: PT. Remaja Rosda Karya

Wildan, Dadan. 1993. "Persis dalam Pentas Sejarah Islam Indonesia.” Risalah, No.5/XXXI/September

Yatim, Badri, 1999. Sejarah Sosial Keagamaan tanah Suci: Hijaz (Mekah dan Madinah) 1800-1925, Jakarta: Logos 